\title{
IAMJ
}

INTERNATIONAL

AYURVEDIC

MEDICAL JOURNAL

Case Report

ISSN: 2320-5091

Impact Factor: 6.719

\section{A CASE REPORT REGARDING MANAGEMENT OF KAMALA THROUGH AYURVEDA}

\section{Charu Sharma}

Associate Prof. Department of Kaya Chikitsa, Quadra Institute of Ayurveda Roorkee

Haridwar, Uttarkhand, India

Corresponding Author: charu22jan@gmail.com

\section{https://doi.org/10.46607/iamj3609112021}

(Published Online: November 2021)

Open Access

(C) International Ayurvedic Medical Journal, India

Article Received: 23/10//2021 - Peer Reviewed: 05/11/2021 - Accepted for Publication: 06/11/2021

D) Check for updates

\begin{abstract}
Ayurveda is traditionally skilful in treating liver diseases for centuries. Although named Jaundice as a liver disorder was not mentioned in Ayurveda literature but based on common characteristics and Pathology, Kamala can be correlated with jaundice. Jaundice is a clinical manifestation of disorders of underlying bilirubin metabolism, hepatocellular dysfunction, or biliary obstruction. Jaundice occurs in settings of cholestasis or inability to effectively secrete bile as well as disorders of bilirubin metabolism and hepatocellular dysfunction. Today's lifestyle with unhygienic and poor dietary habits and alcoholic habits, etc are responsible factors to promote hepatic damage which is clinically reflected as Kamala. This paper discusses a patient seen in the OPD of Kayachikitsa Quadra Institute of Ayurveda Roorkee Haridwar. Her chief complaints Udara shool (pain in the abdomen), Kshudha Mandhya (loss of appetite), Daurbalya (weakness), Hrullas (Nausea), Mutrapitata (yellow discolouration of urine, Vibhandha (constipation) for 15 days. This patient was effectively treated by the combination of Kutaki Churna, Triphala, Trivrita Churna, Bhunimba Churna, Arogya Vardhini Vati, Phalatrikadi Kashaya, Punarnava Mandoor and Liv 52. All the symptoms showed highly significant results. Hence it can be concluded that these medicines are very effective in patients with jaundice.
\end{abstract}

Keywords: Udara shool, Kshudha mandhya, Daurbalya, Hrullas, Mutrapitata, Vibhandha. 


\section{INTRODUCTION}

In today's era, most people have got addicted to oily, junk food \& alcohol which is a primary cause for the occurrence of hepatic disease. Jaundice, also known as icterus, is a yellowish or greenish pigmentation of the skin and whites of the eyes due to high bilirubin levels. ${ }^{[1]}$ The faces may be pale and the urine dark. ${ }^{[2]}$ Causes of jaundice vary from non-serious to potentially fatal. Jaundice is an inflammatory disease affecting the liver. High bilirubin is divided into two types: unconjugated (indirect) and conjugated (direct). Clinical features of Jaundice are abdominal pain, Nausea, Anorexia, Fatigue. ${ }^{[3]}$ The same clinical features are also explained in the case of Kamala, So, based on common characteristics and Pathology, Kamala (Jaundice) can be correlated with jaundice. Ayurveda has classified Kamala Shakhasrita s also called Ruddhapatha Kaamala (obstructive jaundice) and Koshtasrita is also called Bahupitta Kaamala (haemolytic jaundice). ${ }^{[4]}$

\section{Case Report:}

A 32-year-old female came to OPD of Kayachikitsa Quadra Institute of Ayurveda Roorkee Haridwar with the chief complaints of Udara shool (pain in the abdomen), Kshudha mandhya (loss of appetite), Daurbalya (weakness), Hrullas (Nausea), Mutrapitata (yellow discolouration of urine, Vibhandha (constipation) since 15 days.

\section{History of present illness:}

The patient was asymptomatic before 15 days gradually she developed abdominal pain, nausea, vomiting, weakness, discolouration of urine. The patient has not taken any medication before. For Ayurvedic treatment, he came to our hospital Quadra Institute of Ayurveda in Kayachikitsa outpatient department. The patient was clinically examined and decided to investigate for some biochemical laboratory tests.

\section{History:}

Not significant.

\section{Personal History:}

- Bowel - constipation,

- Bladder-yellowish discolouration of urine

- Appetite - poor

- Sleep- altered

- Built - Normal

- No history of any type of addiction like smoking, alcohol.

\section{Asthavidha Pariksha -}

Assessment of the general condition of the patient:

Table 1: Asthavidha Pariksha

\begin{tabular}{|l|l|}
\hline Naadi & Kaphaja \\
\hline Mala & Malavshtambha (constipation) \\
\hline Jivha & Malavrit \\
\hline Sabada & Samanya \\
\hline Spersha & Peetavarniya, Anushnasheet \\
\hline Driga & Arakta pitata \\
\hline Aakriti & Samaakriti \\
\hline
\end{tabular}

\section{On Local Examination Clinical Finding As}

On examination of the patient, no abnormality was detected in CVS, CNS and RS. soft and mild Tenderness over the epigastric region in P/A examinations.

Diagnosis - Kamala (Jaundice)

Date of attending OPD-04/08/2021
In consideration of the findings of clinical examination and investigations (Given in Observation and Result), the following treatment was given.

\section{Treatments Given}

Treatment was given for a period of 45 Days. 
Table 2: Medicine

\begin{tabular}{|l|l|}
\hline Kutaki churna & $1 \mathrm{gm}$ \\
\hline Triphala & $1 \mathrm{gm}$ \\
\hline Trivrit Churna & $1 \mathrm{gm}$ \\
\hline Bhunimba Churna & $1 \mathrm{gm}$ \\
\hline & $1 \times 2$ with Lukewarm water after meal. \\
\hline
\end{tabular}

1. Aarogyavardhani Vati-2-tab BID

2. Punarnava Mandoor - 1 tab BID

3. Phalatrikadi Kashaya - $20 \mathrm{ml}$ BID

4. Syp Liv. 52 - $10 \mathrm{ml}$ TID

\section{Pathya ahara and vihara-}

\section{AHARA}

Carbohydrate rich diet- bread, rice, potato, yam, custard, sugarcane juice, Cereals - Old rice (Oriza Sativa), Barley (Hordeum vulgare), Godhuma (wheat). Pulses
- Adhaki (red gram-Cajamus cajan), Kulattha (horse gram), Mudga (green gram) Vegetables - leafy vegetables like lettuce and spinach. Fruits - Orange, Watermelon, Apple, Jambu (Syzigium cumini), Kapitha (Feronia limonia), grapes, pears, carrot and beets. Avoid fried and fatty food.

2. VIHARA- (LIFESTYLE MODIFICATION)Aasanas (Gomukhasana, Nokasana, Matsyendrasana, Dhanurasana) kapalbhati pranayama.

\section{RESULT}

Table 3: Showing Changes in Blood Investigation during Treatment

\begin{tabular}{|l|l|l|l|l|}
\hline Assessment Parameters & $04 / 08 / 2021$ & $20 / 08 / 2021$ & $04 / 09 / 2021$ & $20 / 09 / 2021$ \\
\hline Sr. Bilirubin total & 4.62 & 4.02 & 1.15 & 0.96 \\
\hline Direct & 2.02 & 1.59 & 0.67 & 0.42 \\
\hline Indirect & 2.74 & 1.83 & 0.74 & 0.54 \\
\hline SGOT & 97 & 39 & 40 & 17 \\
\hline SGPT & 118.9 & 51.80 & 19.48 & 14 \\
\hline
\end{tabular}

During the treatment, the patient was kept only on oral medication for a period of 1 month 15 days. Thus, after one month 15 days of treatment, the patient had got significant improvement in all symptoms. Now the patient is gradually improving and there is no recurrence of symptoms after the 45 days of follow up.

The results were appreciable in both the clinical and laboratory criteria. Statistically, relief in the yellowish colour of eyes and urine, loss of appetite, weakness and reduction in serum bilirubin levels.

\section{DISCUSSION}

In today's era of industrialization and life-threatening competition, the lifestyle of mankind has been hugely changed. In Ayurvedic Samhita, Kamala is explained under Raktavaha Strotas Vyadhi. Regular consumption of Ushna-Tikshna Ahara by Pandurogi causes vitiation of Pitta Dosha. Due to Katu, Amla Lavan Ahara there is vitiation of Pitta which leads to hypofunction Jatharagni followed by the production of Amavisha, and the formation of the disease called Kamala. As it is Pitta and Rakta Pradoshaj Vyadhi it will be managed by Madhura Tikta and Kashaya Rasa. In Ayurveda, various formulations are described for the management of Kamala as a supportive medicine. In this case study formulations like Arogyavardhini Vati, Liv.52, Phalatrikaadi Kwath and Punarnava Mandoora, Triphala Churna, Kutaki Churna, Trivrit Churna, Bhonimbadi Churna are used for the management of kamala. All these Ras Aoushadhi \& herbomineral formulations contain the drugs having Tikta Rasa, Dipana, Pachana, Rechan, Pittakaphashamaka, Yakruttotejaka and Rasayana properties.

Mode of Action of Drugs-

Kutaki [5] is Rechak, dipan, raktashuddhikara, malabhedani, Triphala ${ }^{[6]}$ is Pittaghna, pittavirechaka, anuloman, rasayani, jwaraghna, dipan, 
kamalahara, Trivruta ${ }^{[7]}$ is Anuloman, pittaghna, Bhunimba ${ }^{[8]}$ is Pitta sarak, yakrit uttejak and Rechan.

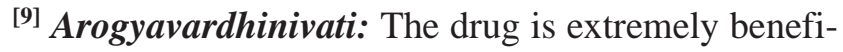
cial in Cirrhosis of the liver, jaundice and case of poor liver functioning, the formulations of Arogyavardhanivati contains Tikta Rasatmak dravyas predominantly Tikta Rasa compose of Vayu and Aakash mahabhoot that causes Dosha Paachana. Significant results were noted in Lakshana the like Anorexia and Vomiting were seen in the patient, indicating the action of the formulation mainly on Agni and Yakruta.

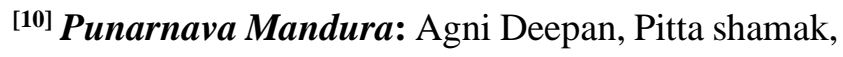
Rasayana, Amanashaka, Pachana, Vatanulomaka.

${ }^{[11]}$ Phalatrikadi Kashaya Pittahara, Pitta Recana, Yakriduttejaka, Dipana, Recana, Shothahara, Jvarahara, Kamala-hara, Pandu-hara, KaphaPitta Shamaka, Tridoshahara, Rasayana, Kshayaghna.

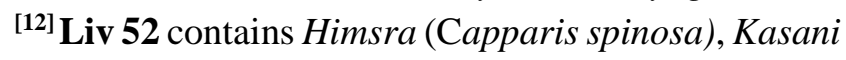
(Cichorium intybus), Mandur Bhasma (Ferric oxide calx), Kakamachi (Solanum nigrum), Arjun (Terminalia arjuna), Kasamarda (Cassia occidentalis), Bhiranjasipha (Achillea millefolium), Jhavuka (Tamarix gallica), all these drugs are being used to improve functional efficacy of liver with antioxidant, stimulant, antibacterial property.

\section{CONCLUSION}

From the above case study, it can be concluded that effective treatment of Kamala is possible by Ayurveda. In patients with jaundice, there was a marked reduction of symptoms like yellowish discolouration of the skin, icterus, yellowish discolouration of urine, Anorexia. No unwanted effect of the medicine was observed during treatment and during follow up period. As this was a single case study, if taken on large sample size, the treatment of Kamala can be emphasised more effectively for the betterment of society.

\section{REFERENCES}

1. Davidson, Edited by brain R. Walker, Davidsons Principles and practice of medicine,22nd edition, Diabetic neuropathy, page 831, year-2006

2. Shastri A, Shusruta samhita with Hindi commentary, chikitsa sthana, chapter 1, Verse 3, Reprinted. Varanasi, Chaukhamba Sanskrit Sansthan Prakashan;2013:1
3. K. Mathew George, Medicine, Elsevier Reed Elsevier India Pvt. Ltd, Reprinted 2016, P.NO 431.

4. Kushawaha, Charak Samhita, Chikitsa Sthan 16/36, Chaukhambia Orientalia, Varanasi, Reprint edition 2012, p.441.

5. Bhattacharya S.K., Satyam K.S and Ghoshal K.S. antioxidant activity of glycowithanlides from withania somnifera. Indian journal exp. Biol; 1997 vol 35 pp236239.

6. Shukla V, Tripathi R (editors). Charak samitha of Agnivesha, Nidana sthana, Chapter 4, Verse 47. Chaukhamba Sanskrit Pratishthan Delhi, Reprint 2006.

7. Shastri AD, Shastri R, (editors), Bhaisjyaratnavali, Chapter 93. Chaukhmba Prakashan, varanasi; reprinted 2015: 1193.

8. Bhavmishra, Edited by Chunekar KC, Pandey GS. Bhav Prakash Nighantu, Varanasi, Chaukhamba Bharti Academy; 2006.

9. Ayush Kumar Garg, Amit Singh, Harish Vishnoi, Gulab Chand Meena, Chandan Singh, Manoj Adlakha. Swine Flu- The Changing Scenario and Preparedness with Formulation of "Win Flu Air Freshener Gel. International Journal of Ayurveda and Pharma Research. 2017;5(11):14-20.

10. Ayush Kumar Garg, Chandan Singh, Manoj Kumar Adlakha. Traditional Relation between Ayurveda and Modern Medicine on the molecular basis. Indian Journal of Agriculture and Allied Sciences.2017, 3(4):133137, Available from: http://www.ijaas.org.in

11. Ayush Kumargarg Et Al: Role of Medhya Rasayan in Geriatric Health Care W.S.R. To Mental Health. International Ayurvedic Medical Journal \{online\} 2017 \{cited February,2017\} Available from: http://www.iamj.in/posts/images/upload/330_337.pdf

12. Malik K. K., M. B. Pal Role of Liv.52 in hepatitis and Cirrhosis of the liver, Current Medical Practice (1979):23,5.

\section{Source of Support: Nil Conflict of Interest: None Declared}

How to cite this URL: Charu Sharma: A Case Report Regarding Management Of Kamala Through Ayurveda. International Ayurvedic Medical Journal \{online\} 2021 \{cited November 2021\} Available from: http://www.iamj.in/posts/images/upload/2866_2869.pdf 